\title{
Neuromuscular monitoring: does it make a difference?
}

R. Martin MD, I. Bourdua MD, S. Thériault MD, J.P. Tétrault MD, M. Pilote RN
Objectif: Le but de la présente étude était d'évaluer l'influence de l'utilisation d'un monitorage de curarisation sur le niveau de curarisation et ce, de l'induction de l'anesthésie jusqu'à l'extubation de la trachée.

Méthode: Quarante-deux patients âgés de 18 à 73 ans prévus pour différentes chirurgies sous aneșthésie générale ont été répartis au hasard en deux groupes de 21 patients. Dans les deux groupes un moniteur Datex NMT® a été utilisé et les réponses électromyographiques des muscles de l'éminence thénar suite à une stimulation supramaximale de nerf cubital ont été enregistrées. Dans le groupe 1, l'anesthésiste pouvait voir la main stimulée mais non le moniteur. Dans le groupe 2, l'anesthésiste ne pouvait voir ni la main ni le moniteur. Le même anesthésiste a donné les curares qui étaient de la succinylcholine à $1.5 \mathrm{mg} \cdot \mathrm{kg}^{-1}$ pour l'intubation endotrachéale et du vécuronium à $0.1 \mathrm{mg} \cdot \mathrm{kg}^{-1}$ pour la relaxation neuromusculaire pendant la chirurgie, dose qui était suivie de réinjections de maintien de 1 à $2 \mathrm{mg}$. Une curarisation résiduelle possible a été évaluée en salle de réveil par les valeurs. de saturation et des tests de soutien de la tête.

Résultats: Les patients du groupe 1 ont montré des niveaux de curarisation plus profonds tout au long de la chirurgie, et ceci malgré l'utilisation de doses comparables de vécuronium (10.I mg pour le G1 et $11.2 \mathrm{mg}$ pour le G2). Les valeurs du T, de l'EMG et du train-de-quatre n'étaient pas différentes lors de l'intubation endotrachéale et de l'extubation. Aucun patient $n ' a$ présenté de signes de curarisation résiduelle en salle de réveil.

Conclusion: Cette étude montre qu'avec une même quantité de vécuronium la relaxation neuromusculaire est plus importante lorsqu'il y a utilisation d'un monitorage neuromusculaire simple (évaluation visuelle des mouvements du pouce). Également, en dépit d'un bloc neuromusculaire plus profond dans le groupe avec moniteur, il n'y a pas eu de curarisation résiduelle dans ce groupe en salle de réveil.

Clinical neuromuscular monitoring is frequently but not always used. ${ }^{1,2}$ A local survey of 51 staff anaesthetists revealed that $16 \%$ of anaesthetists used neuromuscular monitoring in $<50 \%$ of cases. Moreover, a recent study of residual curarisation after administration of atracurium or vecuronium by bolus doses or infusions revealed that a peripheral nerve stimulator (PNS) was not used in 
$45 \%$ of the cases. ${ }^{2}$ As staled by Viby-Mogensen: "Many anesthesiologists do not agree with the extensive use of nerve stimulators and argue that they manage quite well without these devices". ${ }^{1}$

The objectives of the present study were to evaluate the influence of a neuromuscular blockade monitor on the level of neuromuscular blockade induced by succinylcholine and vecuronium from the time of induction of anaesthesia until the time of extubation of the trachea.

\section{Methods}

After institutional approval and informed consent 42 patients aged 8-73 yr and free of neuromuscular disorders were randomly distributed into two groups of 21 according to a random number table. They were scheduled for a range of surgical procedures under general anaesthesia including neurosurgery, orthopedic surgery, ophthalmic surgery and gastro-intestinal surgery. In Group I, the anaesthetisl (the same for all the patients) could see the stimulated hand but could not see the monitor. In Group 2, the anaesthetist could see neither the hand nor the monitor. The objectives of the anaesthetist for both groups were: (a) to achieve tracheal intubation after effect of succinylcholine $1.5 \mathrm{mg} \cdot \mathrm{kg}^{-1}$ which was preceded two minutes earlier by vecuronium 0.01 $\mathrm{mg} \cdot \mathrm{kg}^{-1}$ and an induction dose of thiopentone 5-7 $\mathrm{mg} \cdot \mathrm{kg}^{-1}$ or propofol $2-2.5 \mathrm{mg} \cdot \mathrm{kg}^{-1}$; (b) to administer vecuronium $0.1 \mathrm{mg} \cdot \mathrm{kg}^{-1}$ after partial recovery from succinylcholine; (c) to maintain surgical relaxation throughout surgery which would be adequate for an abdominal surgery using maintenance injections of vecuronium 1 or $2 \mathrm{mg}$; (d) to antagonize the neuromuscular block with neostigmine $0.04 \mathrm{mg} \cdot \mathrm{kg}^{-1}$ and glycopyrrolate $0.01 \mathrm{mg} \cdot \mathrm{kg}^{-1}$ and to extubate the trachea when the patient had fully recovered from neuromuscular relaxant and was awake. In Group 1, the trachea was intubated after disappearance of the thumb responses, the first dose of vecuronium was given after the reappearance of one twitch, the presence of only the first or the first and the second thumb movement was maintained throughout the surgery, the neuromuscular antagonists was given when at least the first movement was present, and complete recovery from the neuromuscular relaxant was evaluated by the presence of the four thumb movements, without apparent fade. In Group 2, the anaesthetist intubated the trachea when, according to clinical criteria, succinylcholine had fully relaxed the patient. Vecuronium was given when the patient had recovered from succinylcholine. The maintenance injections of vecuronium were subsequently arbitrarily administered to maintain relaxation adequate for abdominal surgery. The reversal of vecuronium was always given 30 to $40 \mathrm{~min}$ after the last dose of vecuronium in group 2 and the trachea was extubated when the anaesthetist estimated that the patient had fully recovered from his muscular relaxation. Finally, in both groups, the presence of diaphragmatic movement at the time of tracheal intubation was noted as were the lowest oxygen blood saturation in the recovery room, and the ability of the patient to sustain a head lift for $5 \mathrm{sec}$ on arrival in the recovery room. The neuromuscular monitoring used was a Datex NMT Monitor ${ }^{\circledR}$ (PuritanBennett). This is an evoked electromyography (EMG) monitor which utilizes the integration of the EMG response (area under the curve). Surface electrodes were used. The muscle responses of the thenar eminence were studied following stimulation of the ulnar nerve at the wrist with a supramaximal current determined for each patient before the administration of succinylcholine ( 56 $M A \pm 7$ ). Train-of-four ratios, EMG values of $T_{1}$, compared with control, were observed in both groups: (1) at the time of tracheal intubation; (2) at the time of the initial and subsequent injections of vecuronium; (3) at the time of neostigmine/glycopyrrolate injections; (4) at the time of estimated complete recovery from neuromuscular relaxants. Other monitors included: ECG, non-invasive oscillometry blood pressure pulse oximetry, capnography, anaesthetic gas concentrations and oesophageal temperature.

After an initial bolus of sufentanil $0.3-0.5 \mu \mathrm{g} \cdot \mathrm{kg}^{-1}$ or alfentanil $20-30 \mu \mathrm{g} \cdot \mathrm{kg}^{-1}$ which preceded thiopentone $5-7 \mathrm{mg} \cdot \mathrm{kg}^{-1}$ or propofol $2-2.5 \mathrm{mg} \cdot \mathrm{kg}^{-1}$, anaesthesia was maintained with sufentanil 10-20 $\mu \mathrm{g}$ or alfentanil $500 \mu \mathrm{g}$ bolus injections. The patients breathed $\mathrm{N}_{2} \mathrm{O} / \mathrm{O}_{2}$ $(60 \% / 40 \%)$ with isoflurane ( 0.5 to $1 \%$ inspired) throughout surgery and some outpatients received a propofol infusion of 100 to $200 \mu \mathrm{g} \cdot \mathrm{kg}^{-1} \cdot \mathrm{min}^{-1}$. The lungs were mechanically ventilated to maintain $\mathrm{PaCO}_{2}$ between 30 to $40 \mathrm{mmHg}$.

Unpaired $t$ tests were used for comparisons between the two groups for parametric values and chi-squared tests for non-parametric values. A $P$ value $<0.05$ was considered statistically significant.

\section{Results}

There were no differences in the age, sex, height, duration of surgery, duration of anaesthesia or total dose of vecuronium between groups. However, patients in Group 1 weighed more than patients in Group 2 (75.4 $\mathrm{kg}$ vs $66.9 \mathrm{~kg}$ ), (Table I).

The EMG values of $T_{1}$ and the incidence of diaphragmatic movement at the time of tracheal intubation did not differ between the two groups (Table II).

The time from succinylcholine injection and the initial injection of vecuronium $\left(0.1 \mathrm{mg} \cdot \mathrm{kg}^{-1}\right)$ was less in 
TABLE \ Demographic data

\begin{tabular}{|c|c|c|c|}
\hline & $\begin{array}{l}\text { Group I } \\
\text { (neuromuscular } \\
\text { monitoring) }\end{array}$ & $\begin{array}{l}\text { Group } 2 \\
\text { (no neuromuscular } \\
\text { monitoring) }\end{array}$ & $\begin{array}{l}\text { Statistical } \\
\text { probability }\end{array}$ \\
\hline Age (ycars) & $46.6 \pm 14.6$ & $42.2 \pm 16.5$ & N.S. \\
\hline $\operatorname{ex}(F / M)$ & $8 / 13$ & $10 / 11$ & N.S. \\
\hline Weight (kg) & $75.4 \pm 14.8$ & $66.9 \pm 11.8$ & $P=0.047$ \\
\hline Height (cm) & $166.6 \pm 11.6$ & $165.3 \pm 10.4$ & N.S. \\
\hline $\begin{array}{l}\text { Duration of } \\
\text { surgery (min) }\end{array}$ & $91.9 \pm 53.2$ & $122.4 \pm 69.1$ & N.S. \\
\hline $\begin{array}{l}\text { Total dose of ve- } \\
\text { curonium (mg) }\end{array}$ & $10.12 \pm 4.2$ & $11.25 \pm 4.2$ & N.S. \\
\hline
\end{tabular}

(Mcan \pm SD)

TABLE II EMG values of $T_{1}$ and diaphragmatic movements at the time of endotrachcal intubation

\begin{tabular}{lll}
\hline & $\begin{array}{l}\text { EMG val- } \\
\text { ues of } \Gamma_{1}^{*} \\
(\% \pm S E M)\end{array}$ & $\begin{array}{l}\text { Diaphragmatic } \\
\text { movements* }\end{array}$ \\
\hline (\% of patients)
\end{tabular}

$* P=$ N.S.

TABLE III Time from succinylcholine administration and first injection of vecuronium and EMG values of $T_{1}$

\begin{tabular}{lll}
\hline & $\begin{array}{l}\text { Time } \\
\min ( \pm S E M)\end{array}$ & $\begin{array}{l}\text { Ealues of } T_{1} \\
(\% \pm S E M)\end{array}$ \\
\hline Group I (ncuromuscular monitoring) & $7.5 \pm 1.2$ & $18.1 \pm 3.9$ \\
Group 2 (no neuromuscular monitoring) & $5.0 \pm 0.2$ & $12.5 \pm 4.1$ \\
\hline
\end{tabular}

$* P<0.05$

the no neuromuscular monitoring group ( $\mathrm{gr} \mathrm{2}$ ), but the EMG values of $T_{1}$ were not different (Table III).

The train-of-four values at the times of vecuronium bolus injections during surgery, before antagonism of neuromuscular blockade and at the time of extubation of the trachea are shown in Figure 1. Neuromuscular block was more profound throughout the surgery in the monitored group ( $\mathrm{gr} 1$ ) than in the non-monitored group ( $\mathrm{gr}$ 2) $P<0.05$, except at the time of reversal of neuromuscular blockade and extubation of the trachea. In the no neuromuscular monitoring group the time from the initial and first maintenance dose of vecuronium was less than in the monitored group but the times between the second and third and between the third and fourth injection were longer in the non-monitored group $(P<0.05)$ (Figure 2).

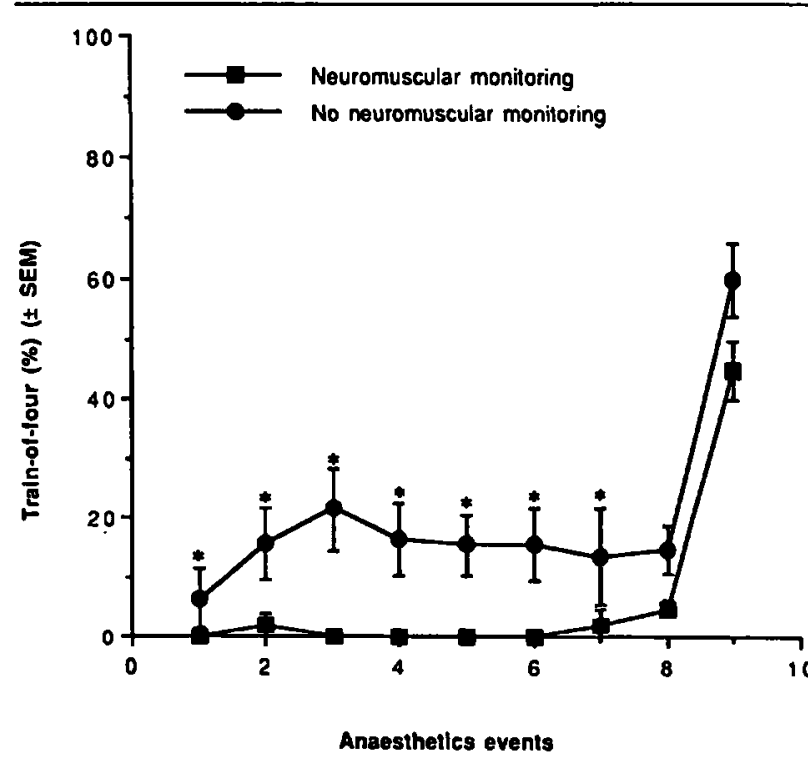

FIGURE 1. Train-of-four ratios expressed in percentage at the times of different anaesthetic events: $1-7=$ Vecuronium $1-2 \mathrm{mg}$ bolus injections during surgery; $8=$ Neuromuscular blockade reversal; $9=$ Extubation of the trachea criteria satisficd. ${ }^{*} P<0.05$ (no monitoring vs monitoring).

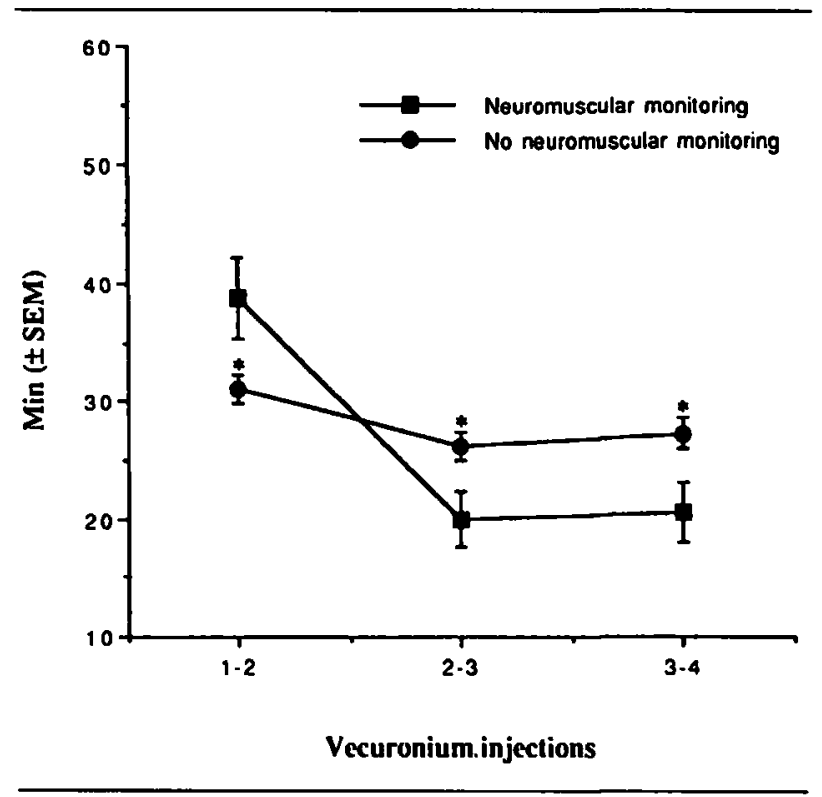

FIGURE 2 Times between first and second, second and third and third and fourth vecuronium injections. ${ }^{*} P<0.05$.

\section{Discussion}

In the present study, according to integrated EMG values, patients where the physician anaesthetist could see the hand stimulated every $20 \mathrm{sec}$ in a train-of-four mode 
had lower train-of-four ratios throughout surgery than did patients with no monitoring (Figure 1). The study also demonstrated that, without monitoring, neuromuscular relaxants are administered at more regular intervals than in the monitored group (Figure 2).

To our knowledge, this is the first time that a study compared the degree of muscular relaxation between one group of patients managed solely by clinical criteria and another group managed with the aid of a neuromuscular monitor. The use of such a monitor was suggested for all patients more than $10 \mathrm{yr}^{\mathrm{ago}^{3}}$ but, as we can observe in our survey and in a recent study, ${ }^{2}$ it is not used for all patients. This monitor is not considered mandatory but "should be immediately available" according to guidelines of practice of anaesthesia in Quebec and in Canada. ${ }^{4.5}$

What are the optimal levels of blockade? In the present study we had gastro-intestinal (G-i) surgery and we tried to produce a neuromuscular block that would be adequate for such a surgery in all patients. According to the train-of-four values showed in Figure 1, the monitored group had a neuromuscular block level adequate for G-i surgery, but this was not the case in the nonmonitored group where the four responses to train-offour stimulation were always present.

The problems with the present study could be related to the small number of patients studies $(n=42)$ and to the fact that a single observer assessed all the cases. The small number of patients is not a problem when we find statistically significant results as in the present study. Also, a single observer might be considered to be an advantage, because the same evaluation criteria were used rigorously for all the patients.

The clinical relevance of the study is that the same amount of vecuronium was used in the two groups of patients with differents results. It shows that a more profound block can be obtained with good timing of neuromuscular relaxant administration.

The results of the present study apply only to vecuronium which is a neuromuscular relaxant of intermediate duration. It is not surprising that no case of residual curarization as evaluated by a very sensitive test (head lifts tests) was observed with this drug. ${ }^{6}$ When possible, this test is less misleading than tactile and visual evaluation of double burst and train-of-four response, ${ }^{7-8}$ the latter being better then no monitoring at all during the surgery. ${ }^{9}$

In conclusion, a deep neuromuscular block was obtained in the group of patient monitored with a simple neuromuscular block monitoring. Such a deep block was not achieved in a group of patient without neuromuscular monitoring. No signs of residual curarisation were observed in the recovery room in any patient.

\section{References}

I Viby-Mogensen J. Neuromuscular monitoring. In: Miller RD (Ed.). Anesthesia, 4th ed. New York: Churchill Livingstone Inc., 1994: 1359.

2 Fawcett WJ, Dash A, Francis GA, Liban JB, Cashman JN. Recovery from neuromuscular blockade: residual curarisation following atracurium or vecuronium by bolus dosing or infusions. Acta Anaesthesiol Scand 1995; 39: 288-93.

3 Viby-Mogensen J. Clinical assessment of ncuromuscular transmission. Br J Anaesth 1982; 54: 209-23.

4 Guide de l'exercice de l'anesthéie. Publication de la corporation professionnelle des médecins du Québec, 1992; 6.

5 Directives relatives à l'exercice de l'anesthésie tel que recommandé par la Société canadienne des anesthésistes. Publication de la Société canadienne des anesthésistes, 1987; 9.

6 Bevan DR, Smith CE, Donati F. Postoperative neuromuscular blockade: a comparison between atracurium, vecuronium, and pancuronium. Anesthesiology 1988; 69: 272-6.

7 Viby-Mogensen J, Jensen $N H$, Engbaek J, Ørding $H$, Skovgaard LT, Chraemmer-Jorgensen B. Tactile and visual evaluation of the response to train-of-four stimulation. Anesthesiology 1985; 63: 440-3.

8 Kilts J, Martineau R, Miller D, Hull K, Lindsay P, Curran $M$. Evaluation of the peripheral nerve stimulator vs EMG for monitoring neuromuscular block during continuous infusion of atracurium. Can J Anaesth 1993; 40: A56.

9 Shorten $G D$, Merk $H$, Sieber T. Perioperative train-of-four monitoring and residual curarization. Can J Anaesth 1995; 42: $711-5$. 